\title{
Effect of stocking density on water and soil quality, growth, production and profitability of farming Indian major carps
}

\author{
NARAYAN BAG ${ }^{1 *}$, SANJIB MOULICK ${ }^{2}$ AND BIMAL CHANDRA MAL ${ }^{3}$ \\ Agricultural and Food Engineering Department, Indian Institute of Technology, Kharagpur - 721 302, West Bengal, India \\ ${ }^{1}$ Uluberia - I Dev. Block, P. O. Uluberia R. S - 711 316, West Bengal, India \\ ${ }^{2}$ School of Civil Engineering, KIIT University, Bhubaneswar - 751 024, Odisha, India \\ ${ }^{3}$ Swami Vivekananda Technical University, Bhilai - 490 009, Chhattisgarh, India \\ e-mail:ns8nov2003@yahoo.co.in
}

\begin{abstract}
Indian major carps (IMCs), catla (Catla catla); rohu (Labeo rohita) and mrigal (Cirrhinus mrigala) were cultured at stocking densities of 20000 (T1), 35000 (T2) and 50000 (T3) fingerlings ha ${ }^{-1}$ for a period of 300 days in nine numbers of polythene lined ponds having an average water area of $150 \mathrm{~m}^{2}$. Stocking ratio of catla, rohu and mrigal were 4:3:3. Fishes were fed $35 \%$ protein diet twice daily. Water $\mathrm{pH}$ was maintained within the ideal range (6 - 9) by intermittent liming. Significantly lower $(\mathrm{p}<0.05)$ levels of dissolved oxygen and higher values of total ammonia-nitrogen were recorded at higher stocking densities compared to lower ones. Significantly higher $(p<0.05)$ specific growth rate (SGR) and lower feed conversion ratio (FCR) were recorded in T1 compared to T2 and T3. However, maximum production was recorded in T3 followed by T2 and T1. Highest values of investment as well as income were recorded in T3 followed by T2 and T1. However, the maximum net return was obtained in T1 (₹140147 \pm 7048 ) followed by T3 (₹133694 \pm 7931$)$ and T2 (₹101944 \pm 4857$)$. Further, significantly higher $(\mathrm{p}<0.05)$ profitability (PI) was recorded in T1 $(85.51 \%)$ compared to T2 $(45.03 \%)$ and T3 $(45.04 \%)$. The results clearly showed that profitability of the culture system could not be increased only by increasing stocking densities.
\end{abstract}

Keywords: Fish production, Indian major carps, Profitability, Stocking density, Water quality

\section{Introduction}

Three species of Indian major carps (IMCs) viz., catla, Catla catla (Hamilton, 1822), rohu Labeo rohita (Hamilton, 1822) and mrigal Cirrhinus mrigala (Hamilton, 1822) account for more than $82 \%$ of the total inland aquaculture production in India (FAO, 2003). The composite fish culture (CFC), a distinct polyculture system of IMCs together with exotic carps, is the major freshwater aquaculture technology in the country (Anon., 1992; Jayarama, 1998). In India, stocking density of 4000 - 10000 fingerlings ha $\mathrm{ha}^{-1}$ is generally advocated in an extensive carp culture system (Nandeesha, 1993). Stocking density is considered one of the most important variables in aquaculture as it directly influences survival, growth, behaviour, health, water quality, feeding and finally the total production (Rowland et al., 2006). Large numbers of literature are available on carp culture, with three IMC species or IMCs in combination with exotic carp species with stocking densities varying from 690 to 35000 fingerlings $\mathrm{ha}^{-1}$, with recorded production levels ranging from 600 to $25000 \mathrm{~kg} \mathrm{ha}^{-1}$ year-1 $^{-1}$ in different culture systems (Alikunhi et al., 1971; Lakshmanan et al., 1971; Das et al., 1975, 1977, 1980; Chaudhuri et al., 1974, 1975, 1978; Chakrabarty et al., 1979; Jhingran, 1991; CIFA, 1998; Tripathi et al., 2000; Jena et al., 2002).
In India, generally, extensive or semi-intensive carp culture is recommended as the facilities for aeration, and water exchange needed in intensive farming are still limitations at farm level. However, a recent trend of stocking huge numbers of fingerlings (30000 to 40000 fingerlings ha-1 or even more) in culturable ponds is observed among the fish farmers of West Bengal, the leading state in aquaculture production in India, though the available facilities are not suitable enough for such high stocking density. In the present study, culture of IMCs, catla, rohu and mrigal at three different stocking densities viz., 20000, 35000 and 50000 fingerlings $\mathrm{ha}^{-1}$ respectively were experimented and their effects on water quality, sediment characteristics, fish growth and yield were analysed. The study also aimed to determine the profitability of the culture system with such huge stocking densities without providing aeration or water exchange as these facilities are still limitations at farm level.

\section{Materials and methods}

Study area

The experiments were conducted during June 2006 to April 2007 in the aquaculture farm ( $22^{\circ} 19^{\prime} \mathrm{N}$ and $\left.87^{\circ} 19^{\prime} \mathrm{E}\right)$ of Indian Institute of Technology, Kharagpur, India. The farm 
is located on a gently sloping drainage basin situated at an altitude of $48 \mathrm{~m}$ above the mean sea level.

\section{Fish stocking}

The experiments were conducted in 9 nos. of polythene lined ponds of 0.015 ha area each. The ponds were lined with polythene sheet (Silpauline make, $150 \mathrm{~g} \mathrm{~m}^{-2}, 250 \mu$ thick, UV ray protected and blue in colour) to avoid high seepage loss in the project site. Loamy soil was provided over the lining on the pond bed, to a thickness of about $30 \mathrm{~cm}$ to simulate the natural pond environment. These ponds were numbered as P-I, P-II, P-III up to P-IX. The ponds were divided into three groups and three ponds were selected randomly in each group. Average water area of the ponds was $150 \mathrm{~m}^{2}$ having an average water depth of $1.2 \mathrm{~m}$. To avoid the entry of unwanted animals like frogs and snakes, the pond embankments were fenced with nylon nets.

Three different treatments i.e. stocking density of 20000 (T1) (pond no. P-I, P-IV and P-VIII), 35000 (T2) (pond no. P-II, P-V and P-VII) and 50000 (T3) (pond no. P-III, P-VI and P-IX) fingerlings ha ${ }^{-1}$ with combinations of catla $40 \%$, rohu $30 \%$ and mrigal $30 \%$ were followed. The bottom soil of all the ponds was treated with agricultural lime at the rate of $200 \mathrm{~kg} \mathrm{ha}^{-1}$ (Adhikari, 2006). The ponds were then filled with groundwater. Subsequently, ponds were fertilised with cowdung, single super phosphate and urea at the rate of $3000 \mathrm{~kg} \mathrm{ha}^{-1}, 40 \mathrm{~kg} \mathrm{ha}^{-1}$ and $40 \mathrm{~kg} \mathrm{ha}^{-1}$, respectively as a basal dose to develop good and healthy natural aquatic environment before the stocking of fish fingerlings. Stocking was done in the morning between 07.00 to $09.00 \mathrm{hrs}$ when the temperature of water was comparatively low. Before stocking, fingerlings collected from the local hatchery were subjected to a short bath in 5\% potassium permanganate solution for $1 \mathrm{~min}$ and were subsequently acclimatised in the pond water. The mean initial weights of fingerlings stocked were $16.50 \pm 1.95 \mathrm{~g}, 17.32 \pm 1.33 \mathrm{~g}$ and $17.25 \pm 1.80 \mathrm{~g}$ for catla, rohu and mrigal, respectively.

\section{Feeding and liming}

The fishes were fed pelleted feed containing 35\% crude protein in all the three different treatments. The feed ingredients were collected from local market and pelleted feed was prepared in the laboratory. Proximate composition of ingredients and prepared diets are shown in Table 1 and 2.

The fishes were fed six days in a week. No feeding was carried out on the sampling days and on Sundays. However, feeding was done on Sunday when the sampling day was either on Monday or Saturday to avoid two consecutive days of non-feeding. The total experimental period was 300 days and the total number of feeding days were 246. Feed was applied twice a day at three different water depths with the help of nylon rope and perforated nylon bags. The pelleted feed was provided at the rate of $5 \%$ of fish biomass upto 30 days, $3 \%$ from 31 to 60 days, $2 \%$ from 61 to 165 days, $1 \%$ from 166 to 255 days (winter months) and $1.5 \%$ up to the rest of the experimental period. The requirement of total amount of feed per pond was calculated on the basis of $100 \%$ survival upto $2^{\text {nd }}$ month and $90 \%$ for the rest of the culture period. $\mathrm{pH}$ was maintained within its ideal range (6.5 - 8.5) through the application of lime (Calcium carbonate at $50 \mathrm{~kg} \mathrm{ha}^{-1}$ with an interval of 60 days in T1, 45 days in T2 and 35 - 40 days in $\mathrm{T} 3$.

Table 2. Proximate composition and energy content of formulated feed

\begin{tabular}{ll}
\hline Particulars & Proximate composition (\%) \\
\hline Protein & 34.94 \\
Carbohydrate & 38.11 \\
Fat & 7.39 \\
Ash & 11.4 \\
Moisture & 8.16 \\
Total & 100 \\
\hline
\end{tabular}

Energy content of formulated feed: $15.76 \mathrm{~kJ} \mathrm{~g}^{-1}$.

Production cost of feed: ₹ $12.70 \mathrm{~kg}^{-1}$.

\section{Water quality monitoring}

Water temperature, $\mathrm{pH}$, dissolved oxygen (DO), total ammonia nitrogen (TAN), nitrite-nitrogen, nitrate-nitrogen and orthophosphate were analysed from water samples collected between 08.00 and $09.00 \mathrm{hrs}$ at an interval of 3 days and month-wise average value of each parameter was calculated. The DO and TAN were also recorded at dawn and dusk after every 30 days. For estimation of temperature and DO, a portable DO meter (Oxi 330i) was used. The $\mathrm{pH}$ was

Table 1. Proximate composition of feed ingredients

\begin{tabular}{llllll}
\hline Ingredients/feed & Crude protein (\%) & Crude fat (\%) & Ash (\%) & Moisture (\%) & $\%$ in diet \\
\hline Fish meal & 56 & 8.5 & 17 & 8 & 21.40 \\
Groundnut oil cake (GOC) & 40 & 6 & 9 & 8 & 42.9 \\
Mustard oil cake (MOC) & 25 & 7 & 11 & 10 & 12.35 \\
Rice bran & 13 & 14 & 6 & 8 & 12.35 \\
Wheat flour & 11 & 4 & 8 & 8 & 10.00 \\
Vitamin and mineral mix & - & - & - & - & 1.00 \\
Total & & & & & 100 \\
\hline
\end{tabular}


measured using a pH meter (Systronics, 802). TAN, nitritenitrogen, nitrate-nitrogen and orthophosphate were estimated by spectrophotometric (Spectrophotometer; DR/2500, HACH, USA) method following APHA (1998).

\section{Estimation of soil quality parameters}

Sediment samples were collected twice for each treatment i.e. prior to stocking and after final harvest. The samples from each pond were collected from four to five different locations and mixed thoroughly to get composite soil samples. They were air dried in shade at room temperature, powdered, mixed, partitioned and sieved. Soil $\mathrm{pH}$ (pH meter - Systronics, 802), total organic carbon (Walkley and Black method), total available nitrogen (Alkaline permanganate method using Kjeldahl flask) and total available phosphorus (Bray and Kurtz No. 1 method using Spectrophotometer; DR/2500, HACH, USA) were analysed.

\section{Fish growth parameters}

From each experimental group, 30 fishes of each species from each pond were sampled randomly $(>10 \%$ of total fish stocked in each treatment) at every fortnight and weighed to calculate the species-wise mean weight and to adjust the daily ration for the following two weeks. At the end of the experiment, the fishes were harvested by repeated netting and finally by complete draining of the pond water. After final harvest, species-wise final mean weight, survival rate, specific growth rate (SGR), gross production, net production species-wise contribution and feed conversion ratio (FCR) were calculated using the following formulae:

Survival rate $(\%)=100 \times$ No. of fish harvested / No. of fish stocked

$\operatorname{SGR}\left(\%\right.$ day $\left.^{-1}\right)=10^{2}\left[\left(\ln \mathrm{W}_{\mathrm{t}}-\ln \mathrm{W}_{0}\right) / \mathrm{t}\right]($ Hopkins, 1992)

where $\mathrm{W}_{\mathrm{t}}$ is the weight of fish at time $\mathrm{t}$; $\mathrm{W}_{0}$ is the weight of fish at the time of stocking and $t$ is the culture period in days.

Gross production $\left(\mathrm{kg} \mathrm{ha}^{-1}\right)=$ Final mean weight $(\mathrm{kg}) \times$ Stocking density ha ${ }^{-1} \times$ Survival (\%)
Net production $\left(\mathrm{kg} \mathrm{ha}^{-1}\right)=$ Mean weight gain $(\mathrm{kg}) \times$ Stocking density ha ${ }^{-1} \times$ Survival (\%)

Species-wise contribution $(\%)=100 \times$ Production of a species/ Total production

FCR $=$ Total feed applied/Total weight gain

\section{Economic evaluation}

The field trials were conducted using ponds having 0.015 ha area each. For economical assessment, the results of the experiments were suitably scaled up to 1.0 ha. The total investment (IT) and the gross return (GR) (value of total output) of each treatment were estimated. The net return (NR) and the profitability (PI) of each trial were calculated using the following formulae:

$$
\begin{aligned}
& \mathrm{NR}=\mathrm{GR}-\mathrm{IT} \\
& \mathrm{PI}=\mathrm{NR} / \mathrm{IT} \text { (Abou } \text { et al., 2007) }
\end{aligned}
$$

\section{Statistical analysis}

Data of different water and soil quality, fish growth and economical parameters were analysed by one-way ANOVA with stocking density as the factor. Post-hoc comparisons were made using Duncan's new multiple range test (Duncan, 1955) to detail the significant differences among the treatments $(p<0.05)$. All statistical analyses was performed with SPSS version 17.

\section{Results and discussion}

\section{Water quality parameters}

The mean values of different water quality parameters like temperature, dissolved oxygen (DO), total ammonia nitrogen (TAN), nitrite-nitrogen, nitrate-nitrogen and orthophosphate are presented in Table 3. Month-wise variation of these parameters is shown in Fig. 1(a-g). The mean values of water temperature and $\mathrm{pH}$ did not show any significant differences among the different experimental ponds $(\mathrm{p}>0.05)$. The temperature mostly ranged between

\begin{tabular}{|c|c|c|c|c|c|c|}
\hline \multirow{3}{*}{ Parameter } & \multicolumn{6}{|c|}{ Treatments } \\
\hline & \multicolumn{2}{|c|}{$\mathrm{T} 1$} & \multicolumn{2}{|c|}{$\mathrm{T} 2$} & \multicolumn{2}{|c|}{ T3 } \\
\hline & Mean \pm SD & Range & Mean \pm SD & Range & Mean \pm SD & Range \\
\hline Temp. $\left({ }^{\circ} \mathrm{C}\right)$ & $27.38 \pm 0.12^{\mathrm{a}}$ & $18.0-33.8$ & $27.41 \pm 0.15^{\mathrm{a}}$ & $18.3-33.7$ & $27.40 \pm 0.21^{\mathrm{a}}$ & $18.3-34.7$ \\
\hline $\mathrm{pH}$ & $7.31 \pm 0.05^{\mathrm{a}}$ & $6.46-8.25$ & $7.23 \pm 0.02^{\mathrm{a}}$ & $6.45-8.12$ & $7.25 \pm 0.04^{\mathrm{a}}$ & $6.43-8.11$ \\
\hline $\mathrm{DO}\left(\mathrm{mg} \mathrm{l}^{-1}\right)$ & $5.49 \pm 0.25^{\mathrm{a}}$ & $2.9-10.3$ & $4.35 \pm 0.16^{\mathrm{b}}$ & $1.6-8.2$ & $4.02 \pm 0.06^{\mathrm{b}}$ & $1.2-7.9$ \\
\hline TAN $\left(\mathrm{mg} \mathrm{l}^{-1}\right)$ & $0.58 \pm 0.03^{\mathrm{c}}$ & $0.14-1.23$ & $0.77 \pm 0.01^{\mathrm{b}}$ & $0.15-1.65$ & $0.89 \pm 0.03^{\mathrm{a}}$ & $0.19-1.83$ \\
\hline $\mathrm{NO}_{3}-\mathrm{N}\left(\mathrm{mg} \mathrm{l}^{-1}\right)$ & $0.30 \pm 0.00^{c}$ & $0.09-0.48$ & $0.41 \pm 0.01^{\mathrm{b}}$ & $0.09-0.66$ & $0.47 \pm 0.01^{\mathrm{a}}$ & $0.11-0.66$ \\
\hline $\mathrm{NO}_{2}-\mathrm{N}\left(\mathrm{mg} \mathrm{l}^{-1}\right)$ & $0.04 \pm 0.01^{\mathrm{b}}$ & $0.01-0.08$ & $0.04 \pm 0.00^{b}$ & $0.01-0.09$ & $0.05 \pm 0.00^{\mathrm{a}}$ & $0.01-0.11$ \\
\hline $\mathrm{PO}_{4}-\mathrm{P}\left(\mathrm{mg} \mathrm{l}^{-1}\right)$ & $0.07 \pm 0.01^{\mathrm{b}}$ & $0.01-0.18$ & $0.11 \pm 0.01^{\mathrm{a}}$ & $0.04-0.24$ & $0.12 \pm 0.01^{\mathrm{a}}$ & $0.05-0.26$ \\
\hline
\end{tabular}

Table 3. Water quality parameters recorded in different treatments

Temp: temperature; DO: dissolved oxygen; TAN: total ammonia nitrogen.

The values bearing different superscripts in rows $(a, b, c)$ for the three treatments (stocking densities) for a particular parameter differ significantly $(p<0.05)$. Data are means \pm SD of three replicates. 


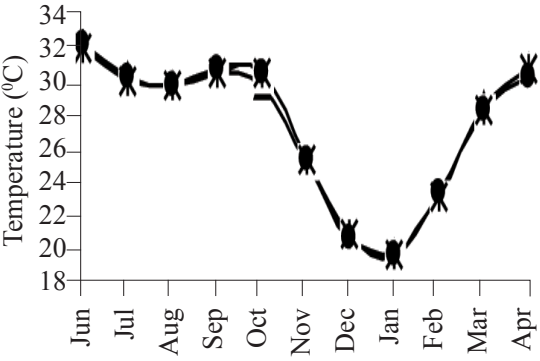

(a)

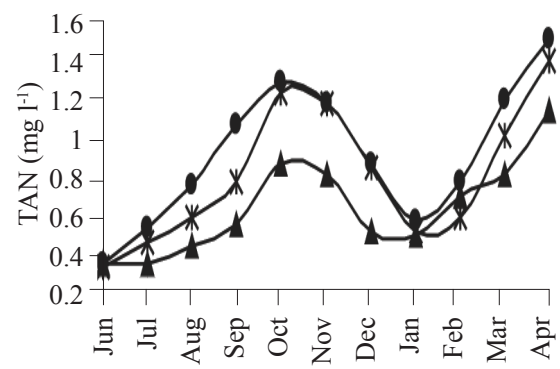

(d)

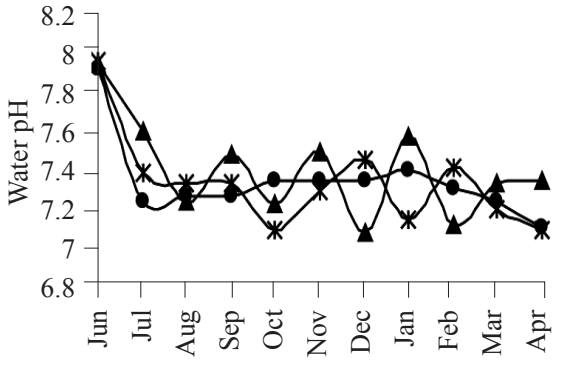

(b)

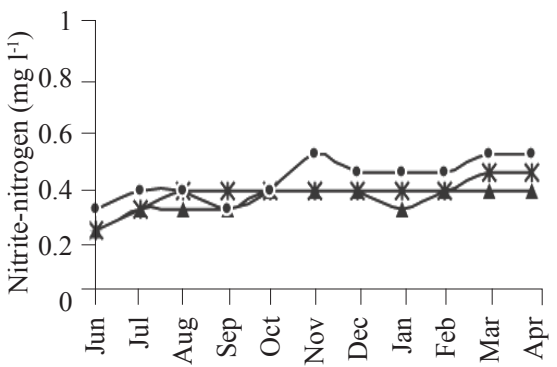

(e)

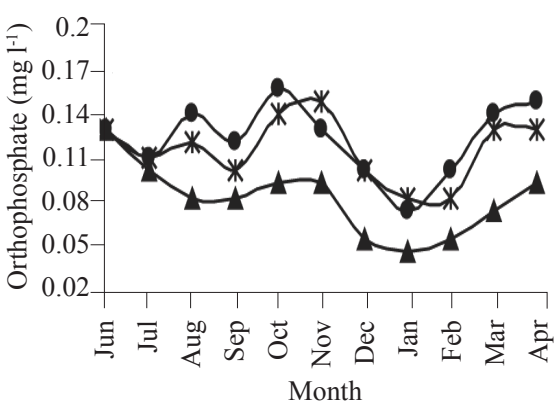

(g)

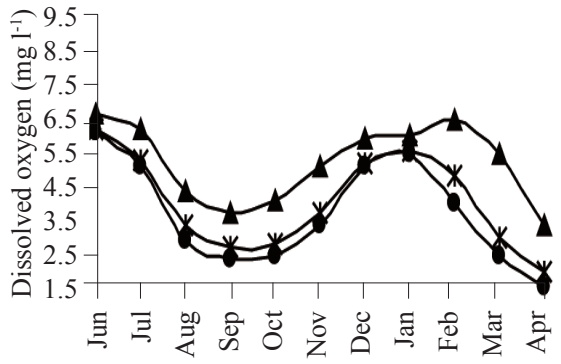

(c)

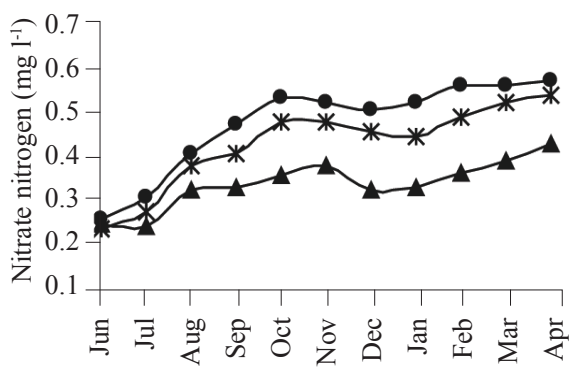

(f)

Fig. 1. Month-wise variation of different water quality parameters in three different treatments: (a): temperature; (b): water pH; (c): dissolved oxygen; (d): total ammonia nitrogen; (e): nitrite-nitrogen; (f): nitrate-nitrogen; (g): orthophosphate

the optimum values of $24-32^{\circ} \mathrm{C}$ (Banerjea, 1967; Adhikari, 2006; Jena and Das, 2006) during the culture period, except from December to first fortnight of February.

The water $\mathrm{pH}$ recorded was within its ideal range (6 - 9) in all three treatments as reported by several workers (Banerjea, 1967; Adhikari, 2006; Jena and Das, 2006). Intermittent application of lime as per requirement enabled the maintenance of $\mathrm{pH}$. Frequent liming was done in higher stocked ponds as the $\mathrm{pH}$ tended to decrease rapidly. This might be attributed to higher biomass holding, leading to increased levels of carbon-di-oxide released through the process of respiration and also due to higher organic load derived from unutilised feed and faecal matter, ultimately resulting in lowering of $\mathrm{pH}$. Similar trends of change in water pH were also recorded by Das et al. (2005) and Sahu et al. (2007).

In the present study, the minimum mean value of DO concentration was recorded in $\mathrm{T} 3\left(4.02 \mathrm{mg} \mathrm{l}^{-1}\right)$ followed by $\mathrm{T} 2\left(4.35 \mathrm{mg} \mathrm{l}^{-1}\right)$ and $\mathrm{T} 1\left(5.49 \mathrm{mg} \mathrm{l}^{-1}\right)$. The values were significantly higher in $\mathrm{T} 1$ compared to $\mathrm{T} 2$ and $\mathrm{T} 3(\mathrm{p}<0.05)$ whereas the values were found insignificant between $\mathrm{T} 2$ and $\mathrm{T} 3(\mathrm{p}>0.05)$. The DO values decreased with the advancement of rearing period except in winter, due to gradual increase in biomass in all the treatments, resulting in higher oxygen demand. Higher concentrations of DO were recorded in winter when the temperature was close to $20^{\circ} \mathrm{C}$.

This was due to the fact that at low temperature, water had high DO saturation capacity and also the consumption of oxygen by fish decreased as the rate of different physiological and biochemical processes of warm water fishes reduced at temperatures lower than $25^{\circ} \mathrm{C}$. Similar trends in DO levels were also reported by Aravindakshan et al. (1997); Jena et al. (2001, 2002); Sahu et al. (2007) and Pawar et al. (2009). The variation of DO and TAN at dawn and dusk for different treatments are presented in Fig. 2(a-b).

At dawn, DO was recorded as low as $1 \mathrm{mg} \mathrm{l}^{-1}$ or even less than that particularly in case of higher stocking densities 


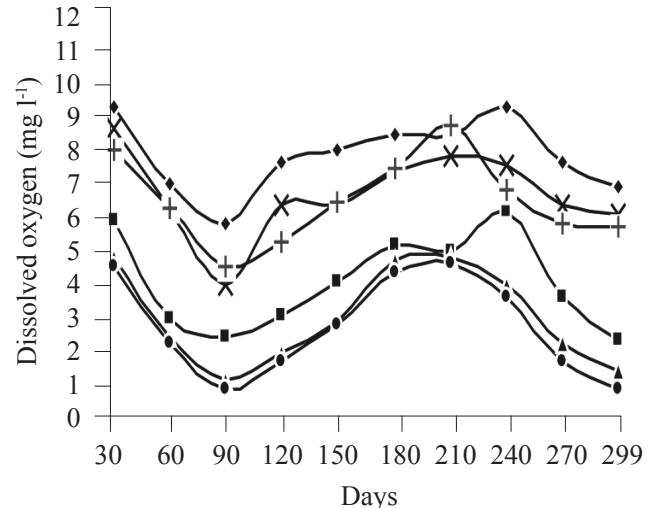

(a)

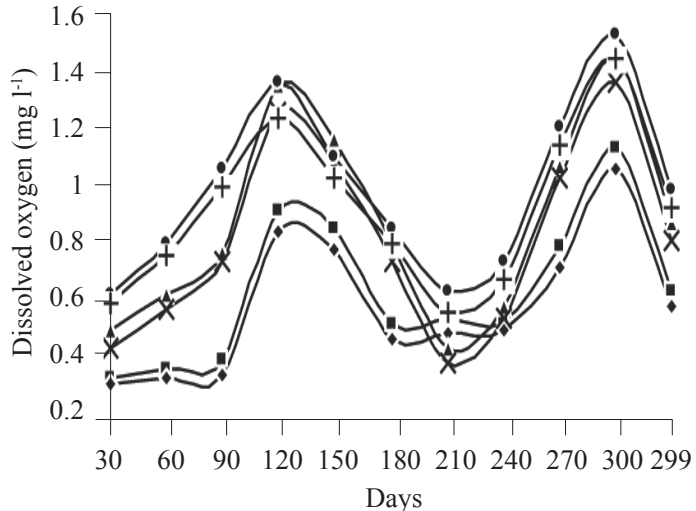

(b)

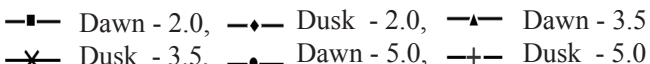

Fig. 2. Water quality parameters at dawn and dusk in different treatments. (a): dissolved oxygen; (b): total ammonia nitrogen

i.e. T2 and T3. According to Aravindakshan et al. (1997), DO is the most important environmental parameter that exerts a tremendous impact on growth and production of fish. DO level above $3 \mathrm{mg} \mathrm{l}^{-1}$ is considered to be essential for fish and other aquatic lives (Banerjea, 1967). According to Jena and Das (2006), DO above $4 \mathrm{mg} \mathrm{l}^{-1}$ is ideal for carp growth whereas Adhikari (2006) suggested that DO concentration ranging from $5 \mathrm{ppm}$ to saturation is ideal for fish growth of all kinds. So, the fishes in the experiments particularly in treatments, T2 and T3 might have been under stress due to very low DO concentration.

Significant variations in TAN among the three different treatments $(p<0.05)$ were recorded. The highest mean value was observed in T3 followed by $\mathrm{T} 2$ and $\mathrm{T} 1$. The results clearly indicate that the higher stocking densities with higher fish biomass were responsible for higher level of TAN. The increased ammonia content recorded with the progress of culture was attributed to the gradual accumulation of metabolites and uneaten feed (Jena et al., 2001, 2002; Sahu et al., 2007). In the early period of culture, due to lower fish biomass and diluted pond water mainly because of sufficient rain, the TAN values were found to be low. In winter, from December up to the first fortnight of February, the concentration recorded was also lower mainly because of lower metabolic activities of warm water fishes due to low temperature. In general, the maximum concentration of TAN was recorded at dawn and the minimum at dusk. The use of TAN by phytoplankton during the day time is probably the reason for this variation. Generally, a difference in values of TAN at dawn and dusk ranging from 0.05 to $0.1 \mathrm{mg} \mathrm{l}^{-1}$ was recorded in different experiments. Ammonia is toxic to fish and is considered to be a major factor limiting fish growth in intensive culture systems (Thurston et al., 1983; Cai and Summerfelt, 1992; Forsberg and Summerfelt, 1992; Leung et al., 1999). It is suggested by several researchers that the
TAN values should be less than $1 \mathrm{mg} \mathrm{l}^{-1}$ for good growth of all aquaculture species (Meade, 1985; Jena and Das, 2006). During the present study, TAN values were found to be more than $1 \mathrm{mg} \mathrm{l}^{-1}$ in the treatments T2 and T3 in the months of October, November and last week of February, March and April.

The values of nitrite-nitrogen ranging from 0.01 to $0.11 \mathrm{mg} \mathrm{l}^{-1}$ and nitrate-nitrogen ranging from $0.09-0.66 \mathrm{mg} \mathrm{l}^{-1}$ in different treatments were recorded which were within safe levels (Meade, 1985; Banerjee and Lal, 1990; Lyssenko and Wheaton, 2006). Concentrations of orthophosphates were significantly lower in $\mathrm{T} 1$ in comparison with $\mathrm{T} 2$ and T3 $(p<0.05)$, but the variations were insignificant between $\mathrm{T} 2$ and T3 ( $>0.05)$. In general, an increasing trend of these inorganic nutrients with the progress of culture was noticed for all the treatments except in winter and comparatively higher concentration was recorded at higher stocking densities.

\section{Sediment characteristics}

The initial and final values of soil $\mathrm{pH}$, total organic carbon, total available nitrogen and total available phosphorus observed during the experiments are presented in Table 4.

The variation in mean values of initial and final soil $\mathrm{pH}$ of all the three treatments were recorded to be insignificant ( $>0.05$ ). The $\mathrm{pH}$ of sediment ranged between 6.73 to 7.20. This was within the optimum range of 6.5 to 7.5 suggested in the previous studies on carp polyculture (Banerjea, 1967; Jana and De, 1988, 1993; Mohanty, 1995; Jena et al., 2002). The intermittent application of lime was useful to maintain the soil $\mathrm{pH}$ within its optimum range. There was no significant variation in mean values of initial total organic carbon, available nitrogen and available phosphorus among three different treatments $(\mathrm{p}>0.05)$. Significantly higher values of final total organic carbon were recorded in T2 
Table 4. Soil quality parameters recorded in different treatments

\begin{tabular}{|c|c|c|c|c|c|c|c|}
\hline \multirow{3}{*}{ Parameter } & \multicolumn{7}{|c|}{ Treatments } \\
\hline & & \multicolumn{2}{|c|}{$\mathrm{T} 1$} & \multicolumn{2}{|c|}{$\mathrm{T} 2$} & \multicolumn{2}{|c|}{$\mathrm{T} 3$} \\
\hline & & Mean \pm SD & Range & Mean \pm SD & Range & Mean \pm SD & Range \\
\hline \multirow[t]{2}{*}{$\mathrm{pH}$} & Initial & $7.07 \pm 0.15^{\mathrm{a}}$ & $6.9-7.20$ & $7.03 \pm 0.11^{\mathrm{a}}$ & $6.9-7.10$ & $6.97 \pm 0.11^{\mathrm{a}}$ & $6.9-7.10$ \\
\hline & Final & $6.91 \pm 0.15^{\mathrm{a}}$ & $6.79-7.08$ & $6.85 \pm 0.08^{\mathrm{a}}$ & $6.76-6.92$ & $6.83 \pm 0.10^{\mathrm{a}}$ & $6.73-6.92$ \\
\hline \multirow[t]{2}{*}{ Total organic carbon (\%) } & Initial & $1.69 \pm 0.03^{\mathrm{a}}$ & $1.66-1.72$ & $1.69 \pm 0.01^{\mathrm{a}}$ & $1.68-1.70$ & $1.68 \pm 0.01^{\mathrm{a}}$ & $1.66-1.69$ \\
\hline & Final & $1.80 \pm 0.06^{\mathrm{c}}$ & $1.73-1.85$ & $1.99 \pm 0.03^{\mathrm{ab}}$ & $1.96-2.02$ & $2.03 \pm 0.06^{\mathrm{a}}$ & $1.98-2.10$ \\
\hline \multirow{4}{*}{$\begin{array}{l}\text { Total available nitrogen } \\
\left(\mathrm{mg} \mathrm{N} 100 \mathrm{~g}^{-1} \text { soil) }\right. \\
\text { Total available phosphorus } \\
\left(\mathrm{mg} \mathrm{P}_{2} \mathrm{O}_{5}-\mathrm{P} 100 \mathrm{~g}^{-1} \text { soil }\right)\end{array}$} & Initial & $45.65 \pm 0.73^{\mathrm{a}}$ & $44.89-46.36$ & $45.39 \pm 1.10^{\mathrm{a}}$ & $44.36-46.55$ & $45.55 \pm 0.58^{\mathrm{a}}$ & $44.96-46.12$ \\
\hline & Final & $49.34 \pm 0.89^{b}$ & $48.36-50.11$ & $52.92 \pm 2.05^{\mathrm{ab}}$ & $51.32-55.23$ & $53.91 \pm 1.13^{\mathrm{a}}$ & $53.26-55.22$ \\
\hline & Initial & $3.33 \pm 0.01^{\mathrm{a}}$ & $3.32-3.35$ & $3.33 \pm 0.06^{\mathrm{a}}$ & $3.28-3.40$ & $3.34 \pm 0.01^{\mathrm{a}}$ & $3.33-3.36$ \\
\hline & Final & $3.56 \pm 0.08^{b}$ & $3.46-3.62$ & $3.67 \pm 0.01^{\mathrm{b}}$ & $3.66-3.68$ & $3.71 \pm 0.02^{\mathrm{a}}$ & $3.69-3.73$ \\
\hline
\end{tabular}

The values bearing different superscripts in rows $(a, b, c)$ for the three treatments (stocking densities) for a particular soil parameter differ significantly ( $<<0.05)$

Data are means $\pm \mathrm{SD}$ of three replicates.

and T3 in comparison with T1 $(\mathrm{p}<0.05)$. The values of final available nitrogen and available phosphorus were also found significantly higher in $\mathrm{T} 3$ compared to $\mathrm{T} 1 \quad(\mathrm{p}<0.05)$. The highest values of final total organic carbon, available nitrogen and available phosphorus were recorded in T3 followed by T2 and T1. This could be attributed to higher biomass holding at higher stocking density leading to higher organic load derived from unutilised feed and faecal matter. According to Banerjea (1967), the sediment organic carbon content in the range of $1.5-2.5 \%$ is considered to be optimum for high fish production in tropical ponds. The mean organic carbon contents ranging from $1.66-2.10 \%$ recorded in different treatments were found almost within the productive range. The mean values of available nitrogen contents ranging from 44.36 to $55.23 \mathrm{mg} \mathrm{N}$ per $100 \mathrm{~g}$ soil recorded in different treatments supported the medium productivity of pond soil for carp culture system as reported by Jena and Das (2006). According to Banerjea (1967) and Jena and Das (2006), the phosphorus contents in the range of $6-8 \mathrm{mg}$ per $100 \mathrm{~g}$ soil is considered optimum for high fish production in tropical ponds. In the present study, available phosphorus levels were low, ranging from 3.28 to $3.73 \mathrm{mg}$ per $100 \mathrm{~g}$ of soil which are comparable to the values recorded by Jana and De (1988, 1993), Das et al. (1977) and Jena et al. (2002) in different experimental carp culture ponds.

\section{Fish growth parameters}

The mean values of different fish growth parameters viz., species-wise final mean weight, survival rate, SGR, gross production, net production, species-wise contribution and FCR in different treatments are presented in Table 5. Average weight of catla, rohu and mrigal recorded during sampling are presented in Fig. 3(a-c). Final mean weight of catla and rohu in different treatments was recorded to be significantly low with increase in stocking densities $(\mathrm{p}<0.05)$. However, in case of mrigal, the differences in values between T2 and T3 were insignificant $(\mathrm{p}>0.05)$.

The results of the study confirmed the trends of decrease in growth for all the three species with increased stocking densities supporting the results of the earlier studies in carps (Lakshmanan et al., 1971; Mohanty, 1995; Jena et al., 1998a, b).

The survival levels in all the treatments for all three species remained at very high levels, ranging from 86.6 to $94.7 \%$ which was higher than many earlier studies ( 74.3 to 88.8\%) (Lakshmanan et al., 1971; Chaudhuri et al., 1975; Sinha and Saha, 1980). Higher survival of catla, rohu and mrigal in all the treatments might be attributed to the quality of fingerlings and their ability to cope with low DO and high TAN, though the growth as well as the production were recorded to be unsatisfactory. Low survival rates of catla in comparison with rohu and mrigal in most of the cases indicated sensitivity of this species to low DO concentration. Such low survival of catla has also been reported earlier in outdoor fingerlings rearing in non-aerated earthen ponds (Jena et al., 2005).

The values of SGR of catla and rohu varied significantly among the different treatments $(\mathrm{p}<0.05)$ and the highest values of SGR for catla and rohu were 0.81 and $0.82 \%$ day $^{-1}$ in $\mathrm{T} 1$; followed by 0.60 and $0.72 \%$ day $^{-1}$ in $\mathrm{T} 2$ and 0.57 and $0.68 \%$ day $^{-1}$ in $\mathrm{T} 3$ respectively. On the other hand, the SGR of mrigal in T1 $\left(0.80 \%\right.$ day $\left.^{-1}\right)$ was significantly higher than the other two treatments $(\mathrm{p}<0.05)$, but the values were insignificant between T2 $\left(0.71 \%\right.$ day $\left.^{-1}\right)$ and T3 $\left(0.70 \%\right.$ day $\left.^{-1}\right)$ ( $>0.05$ ). In general, a trend of decrease in SGR with increase in stocking density was observed. Further, among the three species, catla showed the highest sensitivity with regard to stocking densities.

The gross as well as net production of rohu and mrigal increased significantly with the increase in stocking density $(p<0.05)$. Gross and net total production also showed similar trends and the highest value was recorded in T3 (5379 and $4617 \mathrm{~kg} \mathrm{ha}^{-1} 10$ months $^{-1}$ ) followed by T2 (4103 and $3563 \mathrm{~kg} \mathrm{ha}^{-1} 10$ months $^{-1}$ ) and T1 (3583 and $3267 \mathrm{~kg} \mathrm{ha}^{-1}$ 10 months $^{-1}$ ). However, the gross and net production of catla in $\mathrm{T} 2$ was significantly lower compared to $\mathrm{T} 1$ and $\mathrm{T} 3(\mathrm{p}<0.05)$. 
Table 5. Fish growth parameters recorded in different treatments

\begin{tabular}{|c|c|c|c|c|}
\hline \multirow{2}{*}{ Parameters } & \multirow{2}{*}{ Species } & \multicolumn{3}{|c|}{ Treatments } \\
\hline & & $\mathrm{T} 1$ & $\mathrm{~T} 2$ & $\mathrm{~T} 3$ \\
\hline \multirow[t]{4}{*}{ Final mean weight $(\mathrm{g})$} & Catla & $185.94 \pm 3.60^{\mathrm{a}}$ & $100.05 \pm 4.48^{b}$ & $92.06 \pm 2.14^{c}$ \\
\hline & Rohu & $204.58 \pm 3.79^{\mathrm{a}}$ & $148.75 \pm 3.35^{\mathrm{b}}$ & $135.10 \pm 5.66^{\mathrm{c}}$ \\
\hline & Mrigal & $188.64 \pm 4.24^{\mathrm{a}}$ & $146.58 \pm 3.92^{b}$ & $139.36 \pm 3.51^{b}$ \\
\hline & Average/Total & $193.05 \pm 3.88^{\mathrm{a}}$ & $131.79 \pm 3.91^{\mathrm{b}}$ & $122.17 \pm 3.74^{\mathrm{c}}$ \\
\hline \multirow[t]{4}{*}{ Survival rate $(\%)$} & Catla & $92.02 \pm 2.16^{\mathrm{a}}$ & $89.27 \pm 0.64^{\mathrm{ab}}$ & $86.66 \pm 1.64^{b}$ \\
\hline & Rohu & $93.10 \pm 0.67^{\mathrm{a}}$ & $91.86 \pm 0.94^{\mathrm{a}}$ & $91.78 \pm 0.58^{\mathrm{a}}$ \\
\hline & Mrigal & $94.70 \pm 0.21^{\mathrm{a}}$ & $92.10 \pm 0.55^{b}$ & $92.00 \pm 0.25^{\mathrm{b}}$ \\
\hline & Average/Total & $93.14 \pm 0.96^{\mathrm{a}}$ & $90.90 \pm 0.40^{\mathrm{b}}$ & $89.80 \pm 0.64^{b}$ \\
\hline \multirow[t]{4}{*}{ Specific growth rate $\left(\%\right.$ day $\left.^{-1}\right)$} & Catla & $0.81 \pm 0.01^{\mathrm{a}}$ & $0.60 \pm 0.01^{\mathrm{b}}$ & $0.57 \pm 0.01^{\mathrm{c}}$ \\
\hline & Rohu & $0.82 \pm 0.01^{\mathrm{a}}$ & $0.72 \pm 0.01^{\mathrm{b}}$ & $0.68 \pm 0.01^{\mathrm{c}}$ \\
\hline & Mrigal & $0.80 \pm 0.01^{\mathrm{a}}$ & $0.71 \pm 0.01^{\mathrm{b}}$ & $0.70 \pm 0.01^{\mathrm{b}}$ \\
\hline & Average/Total & $0.81 \pm 0.01^{\mathrm{a}}$ & $0.68 \pm 0.01^{b}$ & $0.65 \pm 0.01^{\mathrm{c}}$ \\
\hline \multirow[t]{4}{*}{ Gross production $\left(\mathrm{kg} \mathrm{ha}^{-1}\right)$} & Catla & $1368.47 \pm 20.85^{b}$ & $1250.60 \pm 61.39^{c}$ & $1596.17 \pm 66.65^{\mathrm{a}}$ \\
\hline & Rohu & $1142.77 \pm 20.13^{c}$ & $1435.04 \pm 46.34^{b}$ & $1859.71 \pm 71.85^{\mathrm{a}}$ \\
\hline & Mrigal & $1071.88 \pm 26.15^{\mathrm{c}}$ & $1417.57 \pm 38.31^{\mathrm{b}}$ & $1923.33 \pm 53.77^{\mathrm{a}}$ \\
\hline & Average/Total & $3583.13 \pm 26.99^{c}$ & $4103.21 \pm 144.68^{\mathrm{b}}$ & $5379.20 \pm 190.05^{\mathrm{a}}$ \\
\hline \multirow[t]{4}{*}{ Net production $\left(\mathrm{kg} \mathrm{ha}^{-1}\right)$} & Catla & $1247.01 \pm 19.34^{\mathrm{ab}}$ & $1044.38 \pm 60.46^{c}$ & $1310.18 \pm 61.28^{\mathrm{a}}$ \\
\hline & Rohu & $1046.02 \pm 20.09^{c}$ & $1267.97 \pm 44.68^{\mathrm{b}}$ & $1621.25 \pm 72.57^{\mathrm{a}}$ \\
\hline & Mrigal & $973.86 \pm 25.96^{c}$ & $1250.75 \pm 38.16^{b}$ & $1685.27 \pm 53.12^{\mathrm{a}}$ \\
\hline & Average/Total & $3266.90 \pm 29.89^{c}$ & $3563.10 \pm 142.26^{\mathrm{b}}$ & $4616.70 \pm 184.95^{\mathrm{a}}$ \\
\hline \multirow[t]{4}{*}{ Species-wise contribution (\%) } & Catla & $38.19 \pm 0.65^{\mathrm{a}}$ & $30.47 \pm 0.44^{\mathrm{b}}$ & $29.67 \pm 0.24^{b}$ \\
\hline & Rohu & $31.90 \pm 0.60^{\mathrm{b}}$ & $34.98 \pm 0.11^{\mathrm{a}}$ & $34.57 \pm 0.27^{\mathrm{a}}$ \\
\hline & Mrigal & $29.91 \pm 0.50^{c}$ & $34.55 \pm 0.36^{\mathrm{b}}$ & $35.76 \pm 0.29^{\mathrm{a}}$ \\
\hline & Average./Total & 100 & 100 & 100 \\
\hline \multirow[t]{4}{*}{ Feed conversion ratio } & Catla & $2.60 \pm 0.04^{\mathrm{c}}$ & $3.09 \pm 0.02^{\mathrm{b}}$ & $3.17 \pm 0.01^{\mathrm{a}}$ \\
\hline & Rohu & & & \\
\hline & Mrigal & & & \\
\hline & Average/Total & & & \\
\hline
\end{tabular}

Values bearing different superscripts in rows $(\mathrm{a}, \mathrm{b}, \mathrm{c})$ for the three treatments (stocking densities) of a particular species differ significantly $(\mathrm{p}<0.05)$. Data are means $\pm \mathrm{SD}$ of three replicates.

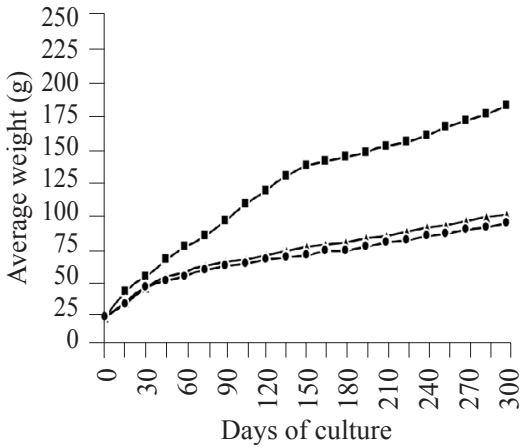

(a)

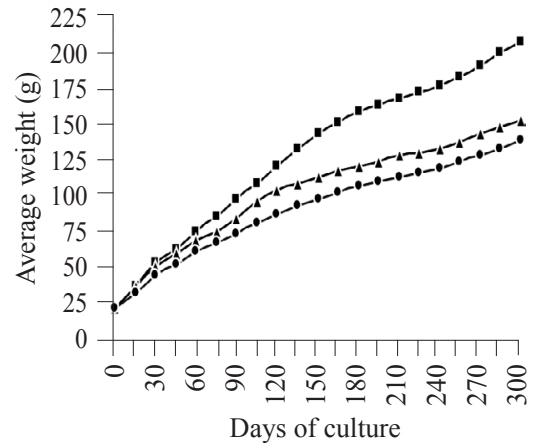

(b)

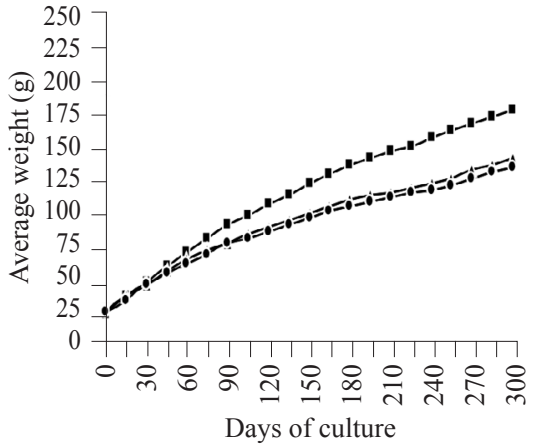

(c)

Fig. 3. Growth performance of IMCs in different treatments. (a): catla; (b): rohu; (c): mrigal

It was mainly due to the $86 \%$ increased growth of catla in T1 over T3 whereas only 9\% higher growth was recorded in T2 compared to T3. The value of gross production of catla was found to be significantly higher in $\mathrm{T} 3$ compared to $\mathrm{T} 1$ $(p<0.05)$, but the difference in net production was recorded to be insignificant between these two treatments $(p>0.05)$.
The results confirm the higher sensitivity of catla to higher stocking densities leading to lower dissolved oxygen and higher TAN levels.

With three IMC species, catla, rohu and mrigal (3.5 : 3.5: 3.0) at a stocking density of 7500 nos. ha- ${ }^{-1}$, Das et al. (1977) recorded gross and net yields of 5,564 and 
$5,174 \mathrm{~kg} \mathrm{ha}^{-1}$ in a culture period of 16 months, with provision of inputs only for 12 months. Further, with these three species, Das et al. (1979) demonstrated similar production levels (5200 $\mathrm{kg}^{-1} \mathrm{ha}^{-1}$ for 13 months) in a pond of lower Sundarbans, West Bengal. Several workers have reported different forms of composite carp culture (both IMCs and exotic carps) in India, with the highest yield of $25000 \mathrm{~kg} \mathrm{ha}^{-1}$ year ${ }^{-1}$ obtained with a stocking density of upto 35000 fingerlings ha $^{-1}$ (Alikunhi et al., 1971; Lakshmanan et al., 1971; Singh et al., 1972; Sinha et al., 1973; Chakrabarty et al., 1972a,b, 1979, 1980; Chaudhuri et al., 1974, 1975; Jhingran, 1991; CIFA, 1998; Tripathi et al., 2000; Jena et al., 2002). In the present experiment, the highest gross and net production of 5379 and $4617 \mathrm{~kg} \mathrm{ha}^{-1}$ in a 10 month period (300 days) were recorded with the stocking density of 50000 fingerlings $\mathrm{ha}^{-1}$. Undoubtedly, the production level recorded in the present study was comparatively low and unsatisfactory. This is due to the lack of proper management practices that should have been adopted for such high stocking density. The necessity of aerators, for increasing production at higher stocking density of more than 15000 fingerlings ha ${ }^{-1}$ has been emphasised by CIFA (1998). Jena and Das (2006) opined that water exchange at regular intervals is essential in highly stocked carp ponds, especially during the later part of the culture period. The results of the present study support their observation.

Contribution of catla in $\mathrm{T} 1$ was significantly higher in comparison with $\mathrm{T} 2$ and $\mathrm{T} 3(\mathrm{p}<0.05)$ and the difference in contribution of catla was found to be insignificant between $\mathrm{T} 2$ and T1 ( $>0.05)$. Significant lower contribution of rohu was recorded in T1 compared to T2 and T3 $(\mathrm{p}<0.05)$ whereas, the difference between $\mathrm{T} 2$ and $\mathrm{T} 3$ in terms of contribution of rohu were insignificant ( $p>0.05$ ). In case of mrigal, the contribution was significantly higher at higher stocking densities $(p<0.05)$. It was also found that in most of the cases the contribution of catla decreased with increased stocking densities and the reverse trend was recorded for mrigal. An increased contribution of mrigal with increased stocking densities may be due to its higher survival that indicates its hardy nature to tolerate the uncongenial environment.

Significant variation of FCR was recorded among the three different treatments $(p<0.05)$ and the highest value was recorded in T3 (3.17) followed by T2 (3.09) and T1 (2.60). These values are comparable to the values reported in literature (Das et al., 1975; Jena et al., 2002), though the stocking densities in all the above studies were much lower than the present study. In the present study, increase in FCR values with increased stocking densities was the general trend. Wedemeyer (1976) reported that high FCR in presence of higher stocking densities may be due to physiological stress imposed by overcrowding. It is well accepted that the feed cost is the greatest operating expense in aquaculture enterprises (De Silva and Anderson, 1995) and therefore efforts must be made for full utilisation of feed in order to maximise growth and feed conversion. The FCR value less than 2.0 or very close to 2.0 is considered to be good in aquaculture industry. From this point of view, the FCR values recorded during the present study, in different treatments are not satisfactory. However, the feed was locally manufactured in the laboratory and was therefore much cheaper than the commercial feed available in the market.

\section{Economic analysis}

The details of investment costs in terms of fingerlings, feed, lime, fertilisers, netting, labour and prophylactics, during culture period and the income as well as profitability generated by selling the fishes are presented in Table 6 . The investment costs varied significantly among the treatments $(\mathrm{p}<0.05)$ with the highest value recorded in T3 (₹296643 $\left.\pm 7400 \mathrm{ha}^{-1}\right)$ followed by T2 (₹226312 $\left.\pm 6728 \mathrm{ha}^{-1}\right)$ and T1 (₹164418 \pm 7915 ha $^{-1}$ ).

With respect to income, higher stocking densities fetched more income and vice versa. Maximum income was obtained from T3 (₹430336 \pm 15204$)$ followed by T2 (₹328257 \pm 11574$)$ and T1 (₹304566 \pm 2294$)$. Maximum selling price of fish was received in $\mathrm{T} 1\left(₹ 85 \mathrm{~kg}^{-1}\right)$ due to better size of fish and from T2 and T3 only ₹80 $\mathrm{kg}^{-1}$ was realised due to smaller sizes of fish during final harvest. Among the three treatments, the maximum net return (NR) was realised in

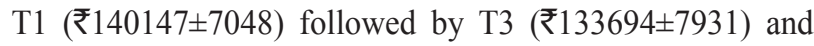
T2 (₹101944 \pm 4857$)$. Significantly lower NR was obtained in T2 compared to T1 and T3 $(\mathrm{p}<0.05)$. The differences in NR were insignificant between T1 and T3 (p>0.05). Further, significantly higher profitability index (PI) was recorded in T1 $(85.51 \%)$ compared to T2 (45.03\%) and T3 (45.04\%) $(p<0.05)$ whereas, the difference in values between T2 and T3 was found to be insignificant $(\mathrm{p}>0.05)$. The results could be attributed to significantly lower fish growth, poor survival rate, significantly higher FCR values, lower market price for small fish and higher investment costs in T2 and T3 compared to T1. Mazid and Alam (1995) reported a net profit of ₹97471.00 ha-1 $\mathrm{yr}^{-1}$ from a carp polyculture system with a stocking density of $6000-9500$ nos. ha-1 ${ }^{-1}$ They also reported a net profit of ₹115746 ha $\mathrm{hr}^{-1} \mathrm{yr}^{-1}$ from red tilapia farming at stocking densities of 20000 nos. ha ${ }^{-1}$. The profitability is the most important parameter for the acceptance or rejection of a scheme or project. In the present study, the net return and the profitability received from the highly stocked ponds were not satisfactory. However, the treatment $\mathrm{T} 1$ realised a net return of about ₹140,000 which is equivalent to a monthly income of about ₹ 11,500 though the growth and production was not up to the satisfactory level. The recent trend of higher stocking in fish farming without proper water exchange and aeration may not be beneficial in terms of net return and profitability. 
Table 6. Investment costs, income and profitability in different treatments

\begin{tabular}{|c|c|c|c|}
\hline Particulars & T1 & $\mathrm{T} 2$ & T3 \\
\hline \multicolumn{4}{|c|}{ A. Investment costs in different treatments (₹) } \\
\hline Lime & 1800 & 2250 & 2475 \\
\hline Cowdung & 1500 & 1500 & 1500 \\
\hline Urea & 180 & 180 & 180 \\
\hline SSP & 160 & 160 & 160 \\
\hline Fingerlings & 20000 & 35000 & 50000 \\
\hline Fish feed & 107798 & 140000 & 185657 \\
\hline Netting & 8000 & 8000 & 8000 \\
\hline Prophylactics and disease prevention & 4000 & 10000 & 14000 \\
\hline Labour for monitoring, feeding etc. & 15000 & 15000 & 15000 \\
\hline Maintenance & 5980 & 14222 & 19671 \\
\hline Total input costs $\left(₹ \mathrm{ha}^{-1} \mathrm{crop}^{-1}\right)$ & $164418 \pm 7915^{\mathrm{c}}$ & $226312 \pm 6728^{b}$ & $296643 \pm 7400^{\mathrm{a}}$ \\
\hline \multicolumn{4}{|l|}{ B. Income from different Treatments } \\
\hline Total production $\left(\mathrm{kg} \mathrm{ha}^{-1} \mathrm{crop}^{-1}\right)$ & $3583 \pm 27^{c}$ & $4103 \pm 145^{b}$ & $5379 \pm 190^{\mathrm{a}}$ \\
\hline Sale price $(₹-1)$ & 85 & 80 & 80 \\
\hline Total income $\left(₹ \mathrm{ha}^{-1} \mathrm{crop}^{-1}\right)$ & $304566 \pm 2294^{c}$ & $328257 \pm 11574^{\mathrm{b}}$ & $430336 \pm 15204^{\mathrm{a}}$ \\
\hline \multicolumn{4}{|c|}{ C. Net return and profitability of different treatments } \\
\hline Net return $\left(₹\right.$ ha $^{-1}$ crop $\left.^{-1}\right)$ & $140147 \pm 7048^{\mathrm{a}}$ & $101944 \pm 4857^{\mathrm{b}}$ & $133694 \pm 7931^{\mathrm{a}}$ \\
\hline Profitability $(\%)$ & $85.51 \pm 8.51^{\mathrm{a}}$ & $45.03 \pm 0.82^{\mathrm{b}}$ & $45.04 \pm 1.62^{\mathrm{b}}$ \\
\hline
\end{tabular}

SSP - single super phosphate: ₹44.50=1.00\$ (Approximate) in 2006 .

The values bearing different superscripts in rows $(a, b, c)$ for the three treatments (stocking densities) differ significantly $(p<0.05)$. Data are means $\pm \mathrm{SD}$ of three replicates.

The results of the present study depicted that the profitability of a culture system cannot be increased only by increasing stocking densities, without proper management practices. Boyd (2003) emphasised implementation of best management practices (BMPs) according to the specific operation allowing the production to be conducted in an economically efficient manner. Therefore, the stocking density, which is one of the most important variable in fish farming, should be fixed according to the facilities available in the farm.

\section{Acknowledgements}

The authors are grateful to the Indian Council of Agricultural Research (ICAR), SMD Sanction No. 16-9/2004-AFC, dated 28.12.2004 for providing the financial support for carrying out the experiments.

\section{References}

Abou, Y., Fiogbe, E. D. and Micha, J. C. 2007. Effect of stocking density on growth, yield and profitability of farming Nile tilapia, Oreochromis niloticus L., fed Azolla diet, in earthen ponds. Aquac. Res., 38: 595-604.

Adhikari, S. 2006. Soil and water quality management in aquaculture. In: Verma, S. A., Kumar, A. T. and Pradhan, S. (Eds.), Handbook of fisheries and aquaculture.Indian Council of Agricultural Research, New Delhi, India, p. 438-457.

Alikunhi, K. H., Sukumaran, K. K. and Parameswaran, S. 1971. Studies on composite fish culture: Production by composite combinations of Indian and Chinese carps. J. Indian Fish. Ass., 1(1): 26-57.

Anon. 1992. Reflections on failure of Indian aquaculture. Fishing. Chimes, 12(7): 1-4.

APHA 1998. Standard methods for the examination of water and wastewater. American Public Health Association. Washington DC, New York.

Aravindakshan, P. K., Jena, J. K., Ayyappan, S., Muduli, H. K. and Chandra, S. 1997. Evaluation of aeration intensities for rearing of carp fingerlings. J. Aquac., 5: 63-69.

Banerjea, S. M. 1967. Water quality and soil condition of fish ponds in some states of India in relation to fish production. Indian J. Fish., 14(1 \& 2): 115-144.

Banerjee, R. K. and Lal, B. 1990. Role of soil and water in fish farming with special reference to primary production. In: Technologies for inland fisheries development. ICAR-Central Inland Capture Fisheries Research Institute, Barrackpore, West Bengal, India, p. 123-129.

Boyd, C. E. 2003. Guidelines for aquaculture effluent management at the farm level. Aquaculture, 226: 101-112.

Cai, Y. J. and Summerfelt, R. C. 1992. Effects of temperature and size on oxygen consumption and ammonia excretion in walleye. Aquaculture, 104: 127-138.

Chakrabarty, R. D., Murty, D. S., Sen, P. R., Nandy, A. C. and Chakraborty, D. P. 1972a. Periodic harvesting to enhance production in composite culture of Indian and exotic carps. In: Proceedings of the silver jubilee symposium: Aquaculture 
as an Industry, ICAR-Central Inland Capture Fisheries Research Institute, Barrackpore, West Bengal, India, 27 pp.

Chakrabarty, R. D., Murty, D. S., Sen, P. R., Nandy, A. C. and Chakraborty, D. P. 1972b. Short term rearing of Indian and exotic carps. In: Proceedings of the silver jubilee symposium: Aquaculture as an Industry, ICAR-Central Inland Capture Fisheries Research Institute, Barrackpore, West Bengal, India, $27 \mathrm{pp}$.

Chakrabarty, R. D., Sen, P. R., Rao, N. G. S. and Ghosh, S. R. 1979. Intensive culture of Indian major carps. In: Pillay, T. V. R. and Dill, W. A. (Eds.), Advances in aquaculture. Fishing News Books, England, p. 153-156.

Chakrabarty, R. D., Sen, P. R., Rao, N. G. S., Ghosh, S. R., Jena, S. and Janikiram, K. 1980. Observations on intensive composite fish culture. Proc. Indo-Pacific Fish. Coun., 19(3): 515-520.

Chaudhuri, H., Chakrabarty, R. D., Rao, N. G. S., Janakiram, K., Chatterjee, D. K. and Jena, S. 1974. Record fish production with intensive culture of Indian and exotic carps. Curr. Sci., 43(10): 303-304.

Chaudhuri, H., Chakrabarty, R. D., Sen, P. R., Rao, N. G. S. and Jena, S. 1975. A new high in fish production in India with record yields by composite fish culture in freshwater ponds. Aquaculture, 6: 343-355.

Chaudhuri, H., Rao, N. G. S., Rout, M. and Kanaujia, D. R. 1978. Record fish production through intensive fish culture. J. Inland Fish. Soc. India, 10: 19-27.

CIFA 1998. Intensive carp culture utilising biotechnological tools for achieving fish production levels of $25 \mathrm{t} \mathrm{ha}^{-1}$ annum ${ }^{-1}$. Project completion report. Central Institute of Freshwater Aquaculture, Bhubaneswar. India, 115 pp.

Das, P., Chatterjee, J. G., Mondal, A. B. and Chakraborty, D. P. 1979. Prospects of carp culture in lower Sundarbans. In: Proceeding of the Symposium on Inland aquaculture, Barrackpore, India, $59 \mathrm{pp}$.

Das, P., Kumar, D. and Guha Roy, M. K. 1975. National demonstration on composite fish culture in West Bengal. J. Inland Fish. Soc. India, 7: 112-115.

Das, P., Kumar, D., Ghosh, A. K., Chakraborty, D. P. and Bhaumik, U. 1980. High yield of Indian major carps against encountered hazards in a demonstration pond. J. Inland Fish. Soc. India, 12(1): 70-78.

Das, P., Sinha, M., Kumar, D., Chakraborty, D. P. and Guha Roy, M. K. 1977. Culture of Indian major carps with record yield in a demonstration pond. J. Inland Fish. Soc. India, 9: 105-110.

Das, P. C., Ayyappan, S. and Jena, J. K. 2005. Comparative changes in water quality and role of pond soil after application of different levels of organic and inorganic inputs. Aquac., Res., 36: 785-798

De Silva, S. S. and Anderson, T. A. 1995. Fish nutrition in aquaculture. Chapman and Hall, London, UK, 334 pp.

Duncan, D. B. 1955. Multiple range and multiple F-Tests. Biometrics, 11: 1-42.
FAO 2003. FAO Yearbook: Fishery statistics of aquaculture production, vol. 92/2 2001. Food and Agriculture Organisation of the United Nations, Rome, $186 \mathrm{pp}$.

Forsberg, J. A. and Summerfelt, R. C. 1992. Effect of temperature on diel ammonia excretion of fingerling walleye. Aquaculture, 102: $115-126$.

Hopkins, K. D. 1992. Reporting fish growth: a review of the basics J. World Aquac. Soc., 23: 173-179.

Jana, B. B. and De, U. K. 1988. Effects of farming management on primary productivity of phytoplankton in fish ponds. J. Aquac. Trop., 3: 95-105.

Jana, B. B. and De, U. K. 1993. Management induced variability of the bacterioplankton in fish farming ponds. J. Aquac. Trop., 8: $131-140$

Jayarama, R. 1998. Economics and technical efficiency in carp culture in Thanjavur District, Tamil Nadu State, India. In: Eide, A. and Vassdal, T. (Eds.), Proceedings of the $9^{\text {th }}$ International Conference of the International Institute of Fisheries Economics and Trade IIFET '98. Tromso, Norway, p. 71-82.

Jena, J. K. and Das, P. C. 2006. Carp culture. In: Verma, S. A., Kumar, A. T. and Pradhan, S. (Eds.), Handbook of fisheries and aquaculture. Indian Council of Agricultural Research, New Delhi, India, p. 265-282.

Jena, J. K., Aravindakshan, P. K. and Mohanty, U. K. 2005. Evaluation of growth and survival of Indian major carp fry in aerated vis-a-vis non-aerated ponds under different stocking densities. Indian J. Fish., 52: 197-205.

Jena, J. K., Aravindakshan, P. K. and Singh, W. J. 1998b. Nursery rearing of Indian major carp fry under different stocking densities. Indian J. Fish., 45(2): 163-168.

Jena, J. K., Aravindakshan, P. K., Chandra, S., Muduli, H. K. and Ayyappan, S. 1998a. Comparative evaluation of growth and survival of Indian major carps and exotic carps in raising fingerlings. J. Aquac. Trop., 13(2): 143-150.

Jena, J. K., Ayyappan, S. and Aravindakshan, P. K. 2002 Comparative evaluation of production performance in varied cropping patterns of carp polyculture systems. Aquaculture, 207: 49-64.

Jena, J. K., Ayyappan, S., Aravindakshan, P. K. and Muduli, H. K. 2001. Comparative evaluation of growth, survival and production of carp species at different stocking densities under polyculture. Indian J. Fish., 48(1): 17-25.

Jhingran, V. G. 1991. Fish and fisheries of India. Hindustan Publishing, New Delhi, India.

Lakshmanan, M. A. V., Sukumaran, K. K., Murty, D. S., Chakraborty, D. P. and Philipose, M. T. 1971. Preliminary observations on intensive fish farming in freshwater ponds by the composite culture of Indian and exotic species. J. Inland Fish. Soc. India, 3: 1-21.

Leung, K. M. Y., Chu, J. C. W. and Wu, R. S. S. 1999. Effects of body weight, water temperature and ration size on ammonia 
excretion by the areolated grouper (Epinephelus areolatus) and mangrove snapper (Lutjanus argentimaculatus). Aquaculture, 170: $215-227$

Lyssenko, C. and Wheaton, F. 2006. Impact of positive ramp short-term operating disturbances on ammonia removal by trickling and submerged-upflow biofilters for intensive recirculating aquaculture. Aquac. Eng., 35: 26-37.

Mazid, M. A. and Alam, M. G. M. 1995. Appropriate technologies for sustainable and environmentally compatible aquaculture development in Bangladesh. In: Ishizuka, K., Hisajima, S. and Macer, D. R. J. (Eds.), Proceedings of the UNESCO University of Tsukuba International Seminar on Traditional technology for environmental conservation and sustainable development in the Asian-Pacific region, Tsukuba Science City, Japan, p. 95-105.

Meade, J. W. 1985. Allowable ammonia for fish culture. Prog. Fish Cult., 47: 135-145.

Mohanty, U. K. 1995. Comparative evaluation of growth and survival of Indian major carp fry in aerated vis-a-vis non-aerated ponds under different stocking densities. M. F. Sc. Thesis, Orissa University of Agriculture and Technology, Bhubaneswar, India, 123 pp.

Nandeesha, M. C. 1993. Aqua feeds and feeding strategies in India. In: New, M. B., Tacon, A. G. J. and Csavas, I. (Eds.), Farm-made aqua feeds. Bangkok, Thailand, p. 213-254.

Pawar, N. A., Jena, J. K., Das, P. C. and Bhatnagar, D. D. 2009. Influence of duration of aeration on growth and survival of carp fingerlings during high density seed rearing. Aquaculture, 290: 263-268.
Rowland, S. J., Mifsud, C., Nixon, M. and Boyd, P. 2006. Effects of stocking density on the performance of the Australian freshwater silver perch (Bidyanus bidyanus) in cages. Aquaculture, 253(1-4): 301-308.

Sahu, P. K., Jena, J. K., Das, P. C., Mondal, S. and Das, R. 2007. Production performance of Labeo calbasu (Hamilton) in polyculture with three Indian major carps Catla catla (Hamilton), Labeo rohita (Hamilton) and Cirrhinus mrigala (Hamilton) with provision of fertilisers, feed and periphytic substrate as varied inputs. Aquaculture, 262: 333-339.

Singh, S. B., Sukumaran, K. K., Chakrabarti, P. C. and Bagchi, M. M. 1972. Observations of composite culture of exotic carps. J. Inland Fish. Soc. India, 4: 38-50.

Sinha, M. and Saha, P. K. 1980. Efficacy of a commercial fish feed for composite fish culture. J. Inland Fish. Soc. India, 12(2): 51-55.

Sinha, V. R. P., Gupta, M. V., Banerjee, M. K. and Kumar, D. 1973. Composite fish culture in Kalyani. J. Inland Fish. Soc. India, 5: 201-208.

Thurston, R. V., Russo, R. C. and Phillips, G. R. 1983. Acute toxicity of ammonia to fathead minnows. Trans. Amer. Fish. Soc., 112: 705-711.

Tripathi, S. D., Aravindakshan, P. K., Ayyappan, S., Jena, J. K., Muduli, H. K., Suresh, C. and Pani, K. C. 2000. New high in carp production in India through intensive polyculture. J. Aquac. Trop., 15: 119-128.

Wedemeyer, G. A. 1976. Physiological response of juvenile coho salmon (Oncorhynchus kisutch) and rainbow trout (Salmo gairdneri) to handling and crowding stress in intensive fish culture. J. Fish. Res. Board Can., 33: 2699-2702. 